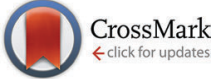

Cite this: Phys. Chem. Chem. Phys., 2015, 17, 8638

Received 2nd December 2014, Accepted 2nd March 2015

DOI: $10.1039 / c 4 c p 05595 k$

www.rsc.org/pccp

\section{Deprotonation of a dinuclear copper complex of 3,5-diamino-1,2,4-triazole for high oxygen reduction activity $\dagger$}

\author{
Masaru Kato, ${ }^{\text {ab }}$ Ken'ichi Kimijima, $\ddagger^{\mathrm{c}}$ Mari Shibata, ${ }^{\mathrm{c}}$ Hideo Notsu, ${ }^{\mathrm{c}}$ Kazuya Ogino, ${ }^{\mathrm{c}}$ \\ Kiyoshi Inokuma, ${ }^{c}$ Narumi Ohta, $\S^{c}$ Hiromitsu Uehara, ${ }^{d}$ Yohei Uemura, $\boldsymbol{q}^{d}$ \\ Nobuhisa Oyaizu, ${ }^{\text {b }}$ Tadashi Ohba, ${ }^{d}$ Satoru Takakusagi, Kiyotaka Asakura*d and \\ Ichizo Yagi*abc
}

\begin{abstract}
A dinuclear copper(II) complex of 3,5-diamino-1,2,4-triazole is one of the highly active copper-based catalysts for the oxygen reduction reaction (ORR) in basic solutions. Our in situ X-ray absorption near edge structure measurements revealed that deprotonation of the triazole ligand might cause coordination geometrical changes, resulting in the enhancement of the ORR activity.
\end{abstract}

Polymer electrolyte fuel cells (PEFCs) generate electricity from oxygen and hydrogen, where only water is produced without the formation of any toxic or greenhouse gases. PEFCs are sustainable power sources for mobile phones, laptop computers and vehicles, and have great potential to shift away from the fossil-fuel economy we have today toward a carbon-emission-free economy, where hydrogen will be used as an energy source. To develop practical PEFCs we need to overcome many technical obstacles, and one well-known bottleneck for the widespread applications of PEFCs is the development of low-cost catalysts for the oxygen reduction reaction (ORR) at the cathode. The best-known electrocatalyst for ORR is the carbon-supported platinum metal. ${ }^{1-4}$ Despite extensive efforts in searching for efficient Pt-based catalysts, platinum is scarce and the Pt-based cathodes still require a large overpotential

\footnotetext{
${ }^{a}$ Faculty of Environmental Earth Science, Hokkaido University, N1ow5, Kita-ku, Sapporo 060-0810, Japan. E-mail: iyagi@ees.hokudai.ac.jp

${ }^{b}$ Graduate School of Environmental Science, Hokkaido University, N10W5, Kita-ku, Sapporo 060-0810, Japan

${ }^{c}$ Fuel Cell Cutting-Edge Center - Technology Research Association (FC-Cubic, TRA), 2-3-26 Aomi, Koto-ku, Tokyo 135-0064, Japan

${ }^{d}$ Catalysis Research Center, Hokkaido University, N21W10, Kita-ku, Sapporo 001-0021, Japan

$\dagger$ Electronic supplementary information (ESI) available: Experimental section and figures of our spectroelectrochemical cell, electrochemical ORR and in situ XANES spectra. See DOI: 10.1039/c4cp05595k

\$ Present address: Institute of Materials Structure Science, High Energy Accelerator Research Organization, KEK, Oho 1-1, Tsukuba, 305-0801, Japan.

$\S$ Present address: Environment and Energy Materials Division, National Institute for Materials Science, 1-1 Namiki, Tsukuba, 305-0044, Japan.

T Present address: Division of Electronic Structure, Department of Materials Molecular Science, Institute for Molecular Science, Myodaiji, Okazaki 444-8585, Japan.
}

of $>200 \mathrm{mV}$ for ORR. It is highly desirable to find low-cost electrocatalysts that can fulfill demands in PEFCs.

In nature multicopper oxidases (MCOs) such as laccases are able to catalyze the ORR with great efficiency. ${ }^{5}$ MCOs reduce oxygen to water at their multi-nuclear copper active site with almost no overpotential (ca. $20 \mathrm{mV}){ }^{6-10}$ It is most unlikely that the enzymes would be used as biocathodes in practical PEFCs, since the enzymes are easily denatured and their footprints are large $\left(c a .160 \mathrm{~nm}^{3}\right.$ for laccase), ${ }^{11}$ resulting in low stability and power outputs, respectively. The active site structures of MCOs, however, have inspired us to design artificial copper-based ORR catalysts, and many bio-inspired electrocatalysts have been extensively studied. ${ }^{12-15}$

A bio-inspired dinuclear copper(II) complex of 3,5-diamino1,2,4-triazole (Cu-Hdatrz, Scheme 1$)^{16}$ supported on carbon black shows high ORR activities in basic solutions. ${ }^{17}$ Although many studies on the Cu-Hdatrz catalyst have been done, for example, its tolerance to poisoning ions ${ }^{18}$ and its ORR activity in a lipid layer, ${ }^{19}$ its detailed catalytic mechanism has not been understood yet. The investigation of the chemical nature of $\mathrm{Cu}$-Hdatrz under reaction conditions will give us insights into such high ORR activities in basic solutions, and will facilitate further development of bio-inspired ORR catalysts.

Here we report electrochemical and in situ X-ray absorption fine structure (XAFS) studies of the carbon-supported Cu-Hdatrz under neutral and basic conditions. In situ XAFS is a powerful technique used to probe the electronic structure or coordination geometry of metal-based electrocatalysts under catalytic conditions. ${ }^{20-22}$ In this

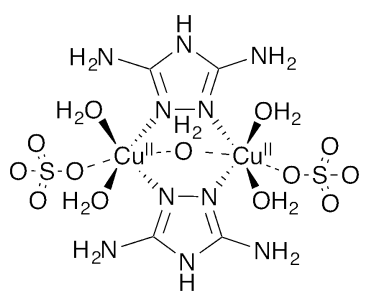

Scheme 1 Molecular structure of the dinuclear copper(॥) complex of 3,5-diamino-1,2,4-triazole (Cu-Hdatrz). 
work we studied X-ray absorption near-edge structure (XANES) spectra of Cu-Hdatrz at various bias potentials under neutral and basic conditions ( $\mathrm{pH} \mathrm{7,10}$ and 13) to understand relationships between deprotonation of the active species and the ORR activity.

A carbon black-supported $\mathrm{Cu}^{\mathrm{II}}$-Hdatrz was synthesized from $\mathrm{CuSO}_{4} \cdot 5 \mathrm{H}_{2} \mathrm{O}$, Hdatrz and Ketjenblack ECP300 (KB), based on the method in the literature with slight modifications (see ESI $\dagger$ ). ${ }^{17}$ $\mathrm{KB}$ is a carbon black material with a relatively high BET surface area $\left(813 \mathrm{~m}^{2} \mathrm{~g}^{-1}\right)$, compared to Vulcan $\left(247 \mathrm{~m}^{2} \mathrm{~g}^{-1}\right)$, which was used as a carbon support in the original catalyst. ${ }^{17}$ Carbon supports with high surface areas, in principle, allow us to load well-dispersed catalysts, which are suitable for fluorescence XANES measurements with high data quality.

Cyclic voltammograms (CVs) of the copper(II) complex of Hdatrz supported on $\mathrm{KB}(\mathrm{Cu} / \mathrm{KB})$ were recorded under $\mathrm{Ar}$ to understand the redox behavior of $\mathrm{Cu} / \mathrm{KB}$ under non-catalytic conditions (Fig. 1). At $\mathrm{pH} 7$ an oxidation wave at $+0.73 \mathrm{~V} v$ s. RHE and a reduction wave at $+0.39 \mathrm{~V} v s$. RHE were observed, and these waves were assigned as: the oxidation wave to $\mathrm{Cu}^{\mathrm{II}}$ and the reduction wave to $\mathrm{Cu}^{\mathrm{I}}$, respectively. The peak separation between these peaks was approximately $0.33 \mathrm{~V}$, which was much greater than $0 \mathrm{~V}$ for electrochemical active species strongly adsorbing on electrode surfaces, indicating that the electrochemical redox behavior of $\mathrm{Cu}$-Hdatrz was irreversible. We also recorded $\mathrm{CVs}$ of $\mathrm{Cu} / \mathrm{KB}$ at $\mathrm{pH} 4, \mathrm{pH} 10$ and $\mathrm{pH} 13$, and obtained similar results for the peak separation. Thus, the redox reaction of $\mathrm{Cu}^{\mathrm{II}}$-Hdatrz may involve structural changes such as geometrical changes around the metal center.

The ORR activity of $\mathrm{Cu} / \mathrm{KB}$ was studied using rotating ring disc electrodes (RRDEs) in buffered aqueous solutions at $\mathrm{pH} 4$, 7, 10 and 13. Linear sweep voltammograms of $\mathrm{Cu} / \mathrm{KB}$ were recorded at $1600 \mathrm{rpm}$ under oxygen (Fig. 2). An onset potential of $\mathrm{Cu} / \mathrm{KB}$ for ORR was observed at $+0.77 \mathrm{~V} v$ s. RHE at $\mathrm{pH} 7$ and the diffusion-limited current reached $c a$. $-1.0 \mathrm{~mA}$. A quite similar ORR activity was observed for Cu-Hdatrz on Vulcan under the same conditions (Fig. S1, ESI $\dagger$ ), suggesting that there was no obvious effect of the carbon supports ( $\mathrm{KB}$ and Vulcan) on the

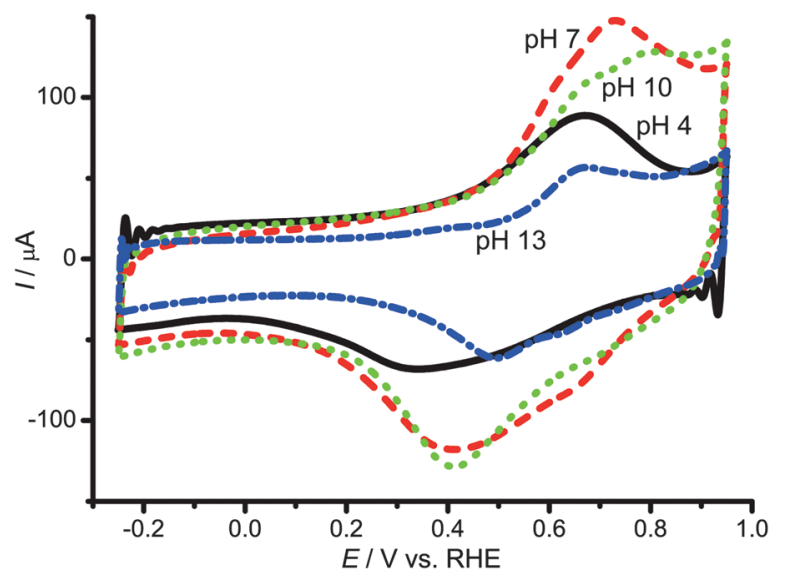

Fig. $1 \mathrm{CVs}$ of $\mathrm{Cu} / \mathrm{KB}$ in Britton-Robinson buffered aqueous solutions (0.04 M) containing $0.1 \mathrm{M} \mathrm{NaClO}_{4}$ at pH 4 (solid line in black), 7 (dashed line in red), 10 (dotted line in green) and 13 (alternate long and short dashed line in blue). All CVs shown here were recorded at a sweep rate of $100 \mathrm{mV} \mathrm{s}^{-1}$ under Ar.
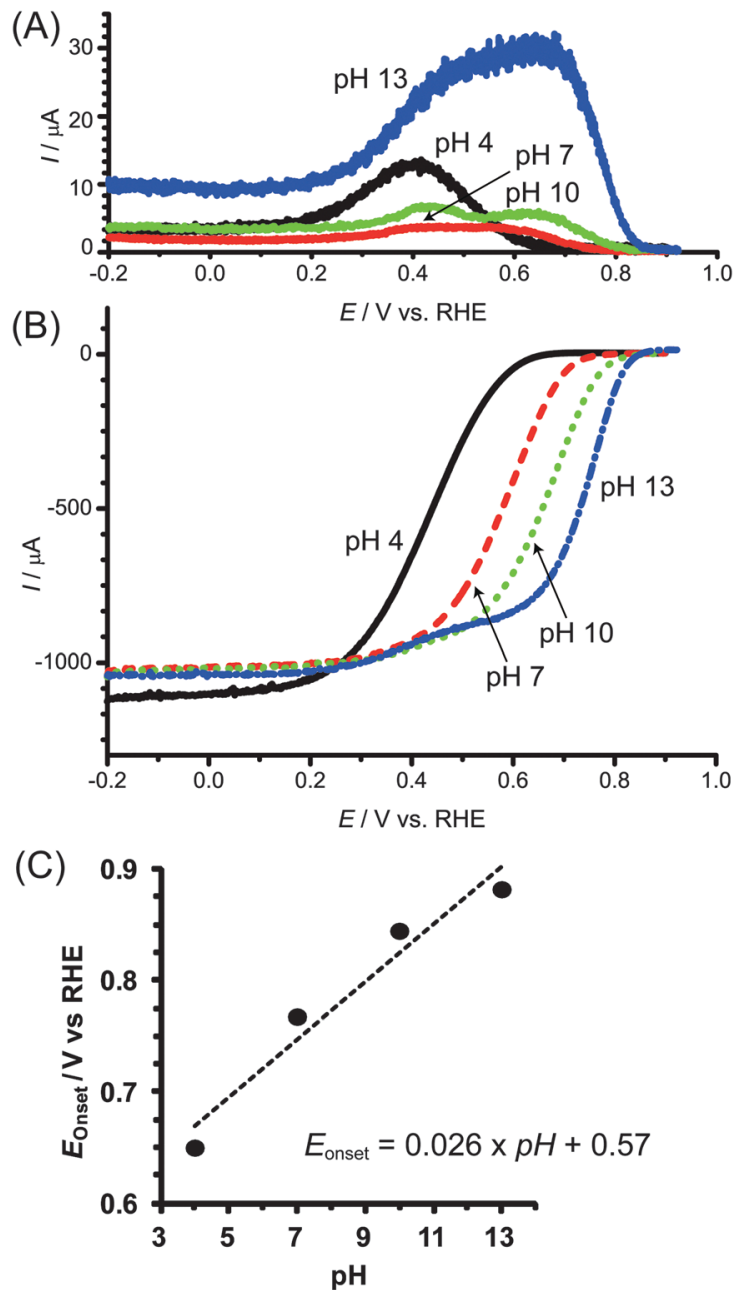

Fig. 2 (A) Ring and (B) disc current of linear sweep voltammograms of Cu/KB using a RRDE (disc: glassy carbon with $0.196 \mathrm{~cm}^{2}$; ring: $\mathrm{Pt}$ ) at 1600 rpm at pH 4 (black), pH 7 (red), pH 10 (green) and pH 13 (blue) under oxygen. The voltammograms were recorded at a sweep rate of $20 \mathrm{mV} \mathrm{s}^{-1}$ scanning in the positive direction. Britton-Robinson buffered aqueous solution $(0.04 \mathrm{M})$ containing $0.1 \mathrm{M} \mathrm{NaClO}_{4}$ was used as the electrolyte solution. A constant bias potential of $1.2 \mathrm{~V}$ vs. RHE was applied to the Pt ring electrode. (C) A plot of onset potential for ORR vs. $\mathrm{pH}$. The plot gave a linear relationship with $E_{\text {onset }}=0.026 \times \mathrm{pH}+0.57$.

catalytic activity. The ring current of $\mathrm{Cu} / \mathrm{KB}$ is less than $5 \mu \mathrm{A}$ at $\mathrm{pH} 7$, indicating almost no hydrogen peroxide generation during ORR. Thus, $\mathrm{Cu} / \mathrm{KB}$ is able to selectively reduce molecular oxygen to water.

The ORR activity of $\mathrm{Cu} / \mathrm{KB}$ depends on $\mathrm{pH}$, and $\mathrm{Cu} / \mathrm{KB}$ is more active in basic solutions than in the neutral solution: the onset potentials for ORR were shifted in the positive direction with increasing $\mathrm{pH}$, and the plot of the onset potential against $\mathrm{pH}$ gave a linear relationship with a slope of $26 \mathrm{mV}$ per $\mathrm{pH}$ (Fig. 2C), which is equivalent to $-33 \mathrm{mV}$ per $\mathrm{pH}$ using a $\mathrm{pH}$-independent reference electrode. This value is approximately half the value of $-60 \mathrm{mV}$ per $\mathrm{pH}$, implying that the rate-limiting step involves the transfer of two electrons and one proton. The same results were reported for $\mathrm{Cu}^{\mathrm{II}}$-Hdatrz supported on a carbon black of Vulcan, where the reduction of two copper centers and the concomitant protonation of a bridging $\mathrm{OH}^{-}$or $\mathrm{O}^{2-}$ ligand occur. ${ }^{17}$ These results suggest 
that carbon supports may not influence the ORR mechanism of $\mathrm{Cu}-\mathrm{Hdatrz}$ in the $\mathrm{pH}$ range from 4 to 13 .

In situ XANES spectra of $\mathrm{Cu} / \mathrm{KB}$ were recorded at $\mathrm{pH} 7,10$ and 13 under catalytic (under $\mathrm{O}_{2}$ ) and non-catalytic conditions (under $\mathrm{N}_{2}$ ) to gain insights into active species during ORR. The potential dependent XANES spectra of $\mathrm{Cu} / \mathrm{KB}$ are shown in Fig. 3. The spectra show isosbestic points, indicating that $\mathrm{Cu}^{\mathrm{II}}$-Hdatrz was electrochemically converted to one reduced species, and a characteristic peak appeared at $\sim 8981 \mathrm{eV}$ in the edge region upon electrochemical reduction. This peak is assigned to the $1 \mathrm{~s} \rightarrow 4 \mathrm{p}_{\pi}$ transition of the $\mathrm{Cu}^{\mathrm{I}}$ complex. ${ }^{22-24}$ Thus, $\mathrm{Cu}^{\mathrm{II}}$-Hdatrz was electrochemically reduced and converted to the $\mathrm{Cu}^{\mathrm{I}}$ species.

Linear combination fitting analysis was performed for the XANES spectra of $\mathrm{Cu} / \mathrm{KB}$, and percentages of $\mathrm{Cu}^{\mathrm{I}}$ species were calculated, assuming that all $\mathrm{Cu}^{\mathrm{II}}$-Hdatrz molecules were reduced at $-0.25 \mathrm{~V} v$ s. $\mathrm{RHE}$ at $\mathrm{pH} 7$, at $-0.08 \mathrm{~V} v$ s. RHE at $\mathrm{pH} 10$ and at $+0.09 \mathrm{~V} v s$. RHE at pH 13 (insets in Fig. 3). Although at pH 7 there was no difference between the amounts of $\mathrm{Cu}^{\mathrm{I}}$ under $\mathrm{N}_{2}$ and $\mathrm{O}_{2}$ (Fig. 3A), more amounts of $\mathrm{Cu}^{\mathrm{I}}$ were observed under $\mathrm{N}_{2}$ than those under oxygen at pH 10 (Fig. 3B) and pH 13 (Fig. 3C). Thus, it is clear that the electrochemical behavior of Cu-Hdatrz under basic conditions is different from that under the neutral conditions.

Considering the amounts of $\mathrm{Cu}^{\mathrm{I}}$ calculated (Fig. 3) and two simplified electron transfer steps (Scheme 2), we concluded that the second electron transfer might be faster in basic solutions than in the neutral solution. The first step is the electron transfer from the electrode or $\mathrm{KB}$ to the $\mathrm{Cu}^{\mathrm{II}}$-Hdatrz complex and the second step is the electron transfer from the $\mathrm{Cu}^{\mathrm{I}}$ species to molecular oxygen (the ORR step). The XANES spectra at $\mathrm{pH} 7$ under $\mathrm{N}_{2}$ and $\mathrm{O}_{2}$ exhibited the same relative amounts of $\mathrm{Cu}^{\mathrm{I}}$ at each potential, indicating that $\mathrm{Cu}^{\mathrm{II}}$-Hdatrz can be immediately reduced to the $\mathrm{Cu}^{\mathrm{I}}$ species even in the presence of oxygen. At pH 10 and pH 13, less relative amounts of $\mathrm{Cu}^{\mathrm{I}}$ were observed under $\mathrm{O}_{2}$ than those under $\mathrm{N}_{2}$, suggesting that the ORR was faster than the reduction of $\mathrm{Cu}^{\mathrm{II}}$-Hdatrz by the electrode or $\mathrm{KB}$ at $\mathrm{pH} 10$. The second electron transfer (the ORR step) may be faster in basic solutions than in the neutral solution, which is consistent with the high ORR activity observed in the basic solution (Fig. 2).

Since XANES spectra are sensitive to coordination geometrical changes around the element measured, the XANES spectra of $\mathrm{Cu} / \mathrm{KB}$ recorded at $\mathrm{pH} 7, \mathrm{pH} 10$ and $\mathrm{pH} 13$ were overlaid to compare their shapes (Fig. 4). Although almost similar shapes of the spectra were observed at $\mathrm{pH} 7$ and $\mathrm{pH} 10$ in the same oxidation state, the XANES spectra at $\mathrm{pH} 13$ were different from those at $\mathrm{pH} 7$ and $\mathrm{pH} 10$, indicating that the coordination geometries of the $\mathrm{Cu}^{\mathrm{II}}$ and $\mathrm{Cu}^{\mathrm{I}}$ centers were the same in the $\mathrm{pH}$ range from 7 to 10 , but these might be different at $\mathrm{pH}$ 13. Furthermore, spectral differences were observed between the XANES spectra under nitrogen and oxygen at pH 13 (Fig. S2, ESI $\dagger$ ). Since the p $K_{\mathrm{a}}$ value of Hdatrz was reported to be $12.12,{ }^{25}$ it is most likely that deprotonation occurred in the Hdatrz ligands at $\mathrm{pH}$ 13. Thus, deprotonation of Cu-Hdatrz in basic solutions may affect the electronic state of the Hdatrz ligands and induce coordination geometrical changes, resulting in a highly active ORR catalyst in basic solutions.

In summary, the electrochemical ORR activity of $\mathrm{Cu} / \mathrm{KB}$ was studied in neutral and basic aqueous solutions using the in situ
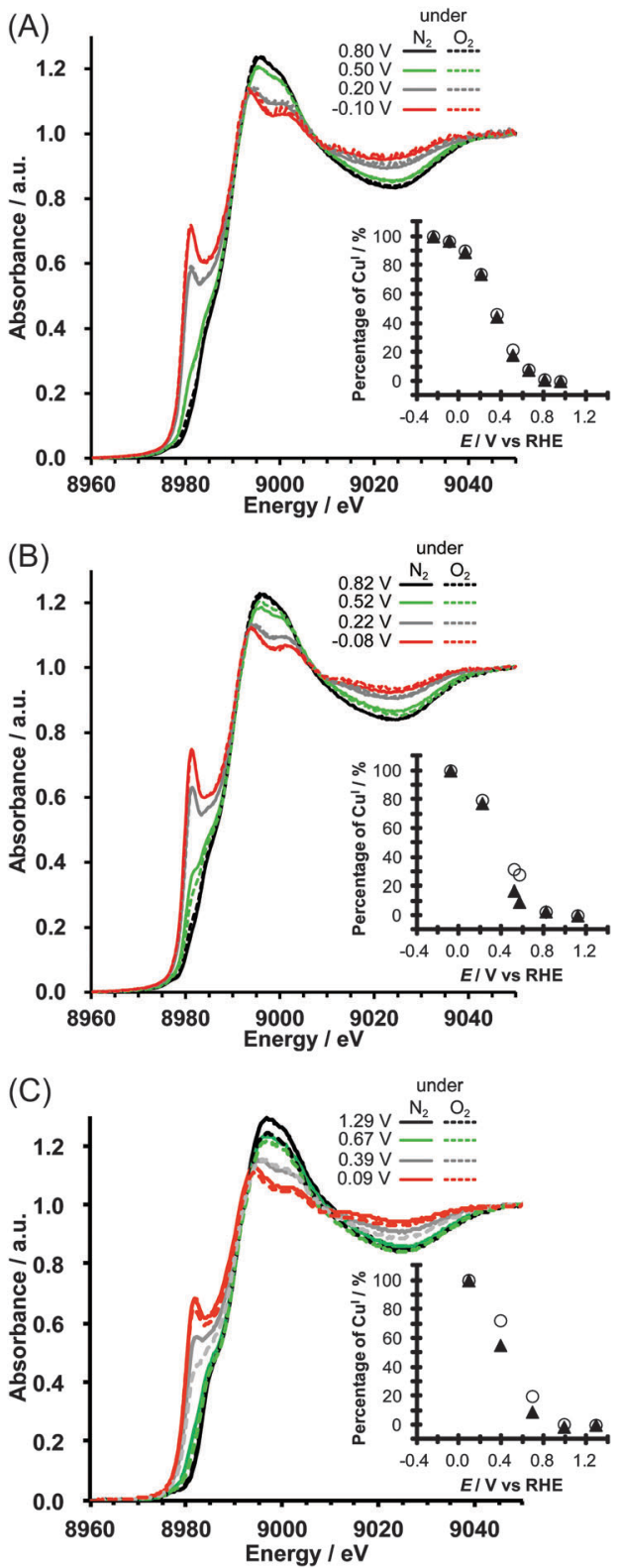

Fig. 3 In situ fluorescence XANES spectra of $\mathrm{Cu} / \mathrm{KB}(\mathrm{A})$ at $\mathrm{pH}$ 7, (B) at $\mathrm{pH} 10$ and (C) $\mathrm{pH}$ 13. The solid line and dashed lines indicate the XANES spectra that were recorded under nitrogen and oxygen, respectively. Insets: plots of percentages of $\mathrm{Cu}^{\prime}$ vs. applied potential (open circle: under nitrogen; filled triangle: under oxygen). The percentages were calculated based on the results of the linear combination analysis of the XANES spectra of $\mathrm{Cu} / \mathrm{KB}$ and fully reduced $\mathrm{Cu} / \mathrm{KB}$.

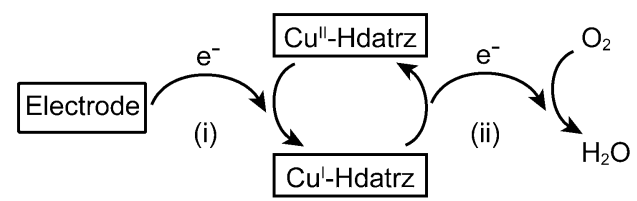

Scheme 2 Simplified electron transfer steps in the $\mathrm{Cu}-\mathrm{Hdatrz} / \mathrm{KB}$ system: (i) electron transfer from the electrode/KB to $\mathrm{Cu}^{\prime \prime}$-Hdatrz and (ii) electron transfer from $\mathrm{Cu}^{\prime}$-Hdatrz to $\mathrm{O}_{2}$ (the ORR step).

electrochemical XANES techniques. Our electrochemical studies revealed that the faster ORR kinetics of $\mathrm{Cu} / \mathrm{KB}$ resulted in the 

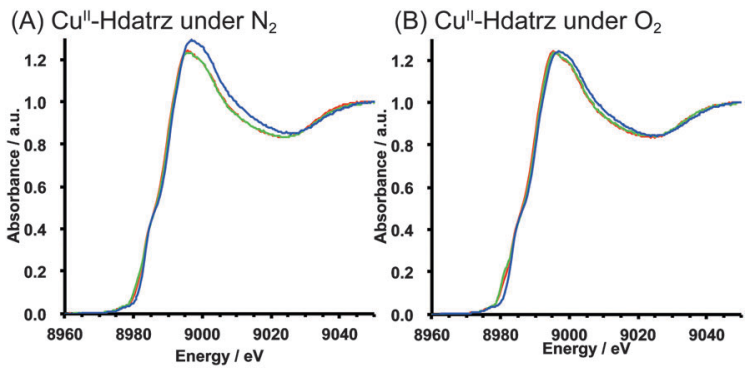

(C) Cu'-Hdatrz under $\mathrm{N}_{2}$

(D) $\mathrm{Cu}^{\prime}$-Hdatrz under $\mathrm{O}_{2}$
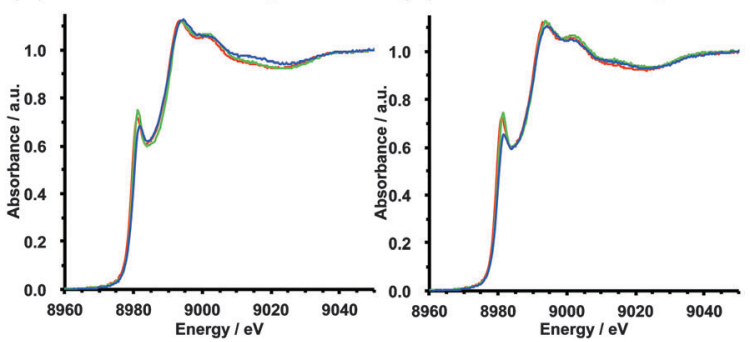

Fig. 4 In situ XANES spectra of $\mathrm{Cu} / \mathrm{KB}$ in the oxidation state of $\mathrm{Cu}^{\prime \prime}$ (A) under $\mathrm{N}_{2}$ and (B) under $\mathrm{O}_{2}$, and in the oxidation state of $\mathrm{Cu}^{\prime}$ (C) under $\mathrm{N}_{2}$ and (D) under $\mathrm{O}_{2}$. The red, green and blue traces indicate the spectra recorded at $\mathrm{pH} 7, \mathrm{pH} 10$ and $\mathrm{pH} 13$, respectively. Bias potentials applied are as follows: $+0.95 \mathrm{~V} v$ s. $\mathrm{RHE}$ at $\mathrm{pH} 7,+1.11 \mathrm{~V}$ vs. RHE at $\mathrm{pH} 10,+1.29 \mathrm{~V}$ vs. $\mathrm{RHE}$ at $\mathrm{pH} 13$ for $\mathrm{Cu}^{\prime \prime}$; $-0.25 \mathrm{~V}$ vs. RHE at $\mathrm{pH} 7,-0.08 \mathrm{~V}$ vs. RHE at $\mathrm{pH} 10$ and $+0.09 \mathrm{~V}$ vs. $\mathrm{RHE}$ at $\mathrm{pH} 13$ for $\mathrm{Cu}^{\prime}$.

higher ORR catalytic activity under basic conditions, compared to that under the neutral conditions. The coordination geometry at $\mathrm{pH} 13$ was different from those at $\mathrm{pH} 7$ and $\mathrm{pH}$ 10, and this difference might be caused by deprotonation of the Hdatrz ligand. The structural information of the deprotonated $\mathrm{Cu}^{\mathrm{I}}$ species or $\mathrm{O}_{2}$-bound intermediates in basic solutions may be a key to understand the high ORR activity of $\mathrm{Cu} / \mathrm{KB}$ or to design highly active Cu-based ORR catalysts.

Further in situ XAFS studies on the Cu-Hdatrz complex are under way to obtain more detailed structural information in basic solutions.

\section{Acknowledgements}

This work has been supported by NEDO and performed under the approval of the Photon Factory Program Advisory Committee (Proposal no. 2010G200 \& 2013G173).

\section{Notes and references}

1 A. A. Gewirth and M. S. Thorum, Inorg. Chem., 2010, 49, 3557-3566.

2 S. Guo, S. Zhang and S. Sun, Angew. Chem., Int. Ed., 2013, 52, 8526-8544.

3 I. Katsounaros, S. Cherevko, A. R. Zeradjanin and K. J. J. Mayrhofer, Angew. Chem., Int. Ed., 2014, 53, 102-121.
4 A. Morozan, B. Jousselme and S. Palacin, Energy Environ. Sci., 2011, 4, 1238-1254.

5 J. A. Cracknell, K. A. Vincent and F. A. Armstrong, Chem. Rev., 2008, 108, 2439-2461.

6 C. F. Blanford, R. S. Heath and F. A. Armstrong, Chem. Commun., 2007, 1710-1712.

7 N. Mano, V. Soukharev and A. Heller, J. Phys. Chem. B, 2006, 110, 11180-11187.

8 P. Olejnik, B. Palys, A. Kowalczyk and A. M. Nowicka, J. Phys. Chem. C, 2012, 116, 25911-25918.

9 V. Climent, Y. Fu, S. Chumillas, B. Maestro, J.-F. Li, A. Kuzume, S. Keller and T. Wandlowski, J. Phys. Chem. C, 2014, 118, 15754-15765.

10 M. S. Thorum, C. A. Anderson, J. J. Hatch, A. S. Campbell, N. M. Marshall, S. C. Zimmerman, Y. Lu and A. A. Gewirth, J. Phys. Chem. Lett., 2010, 1, 2251-2254.

11 K. Piontek, M. Antorini and T. Choinowski, J. Biol. Chem., 2002, 277, 37663-37669.

12 D. Das, Y.-M. Lee, K. Ohkubo, W. Nam, K. D. Karlin and S. Fukuzumi, J. Am. Chem. Soc., 2013, 135, 4018-4026.

13 C. C. L. McCrory, X. Ottenwaelder, T. D. P. Stack and C. E. D. Chidsey, J. Phys. Chem. A, 2007, 111, 12641-12650.

14 M. A. Thorseth, C. S. Letko, T. B. Rauchfuss and A. A. Gewirth, Inorg. Chem., 2011, 50, 6158-6162.

15 M. A. Thorseth, C. E. Tornow, E. C. M. Tse and A. A. Gewirth, Coord. Chem. Rev., 2013, 257, 130-139.

16 E. Aznar, S. Ferrer, J. Borras, F. Lloret, M. Liu-Gonzalez, H. Rodriguez-Prieto and S. Garcia-Granda, Eur. J. Inorg. Chem., 2006, 5115-5125.

17 M. S. Thorum, J. Yadav and A. A. Gewirth, Angew. Chem., Int. Ed., 2009, 48, 165-167.

18 M. S. Thorum, J. M. Hankett and A. A. Gewirth, J. Phys. Chem. Lett., 2011, 2, 295-298.

19 C. J. Barile, E. C. M. Tse, Y. Li, T. B. Sobyra, S. C. Zimmerman, A. Hosseini and A. A. Gewirth, Nat. Mater., 2014, 13, 619-623.

20 K. A. Kuttiyiel, K. Sasaki, Y. Choi, D. Su, P. Liu and R. R. Adzic, Energy Environ. Sci., 2012, 5, 5297-5304.

21 Y. Gorlin, B. Lassalle-Kaiser, J. D. Benck, S. Gul, S. M. Webb, V. K. Yachandra, J. Yano and T. F. Jaramillo, J. Am. Chem. Soc., 2013, 135, 8525-8534.

22 F. Giordanino, E. Borfecchia, K. A. Lomachenko, A. Lazzarini, G. Agostini, E. Gallo, A. V. Soldatov, P. Beato, S. Bordiga and C. Lamberti, J. Phys. Chem. Lett., 2014, 5, 1552-1559.

23 L. S. Kau, D. J. Spira-Solomon, J. E. Penner-Hahn, K. O. Hodgson and E. I. Solomon, J. Am. Chem. Soc., 1987, 109, 6433-6442.

24 E. I. Solomon, D. E. Heppner, E. M. Johnston, J. W. Ginsbach, J. Cirera, M. Qayyum, M. T. Kieber-Emmons, C. H. Kjaergaard, R. G. Hadt and L. Tian, Chem. Rev., 2014, 114, 3659-3853.

25 T. P. Kofman, Russ. J. Org. Chem., 2001, 37, 1158-1168. 